\title{
The African Honey Bee: Factors Contributing to a Successful Biological Invasion*
}

Stanley Scott Schneider, ${ }^{1}$ Gloria DeGrandi-H offman, ${ }^{2}$ and Deborah Roan Smith ${ }^{3}$

${ }^{1}$ Department of Biology, University of North Carolina, Charlotte, North Carolina 28223;

email: sschnedr@email.uncc.edu

${ }^{2}$ Carl Hayden Bee Research Center, 2000 E. Allen Road, Tucson, Arizona 85719;

email: gd-hoffman@tucson.ars.ag.gov

${ }^{3}$ Department of Ecology and Evolutionary Biology, Entomology Program,

University of Kansas, Lawrence, Kansas 66045; email: debsmith@ku.edu

Key Words Africanized honey bee, Apis mellifera scutellata, biogeography, introduced species, invasive organisms

- Abstract The African honey bee subspecies Apis mellifera scutellata has colonized much of the Americas in less than 50 years and has largely replaced European bees throughout its range in the New World. The African bee therefore provides an excellent opportunity to examine the factors that influence invasion success. We provide a synthesis of recent research on the African bee, concentrating on its ability to displace European honey bees. Specifically, we consider $(a)$ the genetic composition of the expanding population and the symmetry of gene flow between African and European bees, $(b)$ the mechanisms that favor the preservation of the African genome, and $(c)$ the possible range and impact of the African bee in the United States.

\section{INTRODUCTION}

Introduced organisms pose worldwide threats to human welfare and the maintenance of biodiversity $(75,112)$. Yet, we often have a poor understanding of the genetic and behavioral mechanisms that make a species a "good invader" $(49,50)$. A model animal for studying invasion success is the African honey bee subspecies Apis mellifera scutellata, which was introduced into Brazil in 1956 in an effort to establish honey bee populations better adapted to tropical conditions. Since its introduction, the African bee has spread throughout Latin America and the southwestern United States $(43,59,60,134,135)$. The colonization of much of the

\footnotetext{
*The U.S. Government has the right to retain a nonexclusive, royalty-free license in and to any copyright covering this paper.
} 
western hemisphere in less than 50 years by a single race of insect is one of the most rapid and spectacular biological invasions known.

One of the more remarkable aspects of the African bee is its ability to displace European honey bee subspecies in the New World. Initially, it was assumed that African and European bees would interbreed, giving rise to the "Africanized honey bee" of Latin America. However, although substantial hybridization occurs when African bees invade areas with European populations (76, 80, 84, 87, 88, 108), over time European characteristics tend to be lost $(6,7,22,43,59,68,77,81,104$, $125,126)$. Indeed, throughout much of its range in the New World, the invading honey bee population has remained essentially African in its nesting biology (62), swarming and absconding behavior $(62,71,91,96,100,102,118)$, foraging and diet selection $(26,99,101)$, and mitochondrial DNA (mtDNA) characteristics $(6$, 7, 43, 104).

The phenomenal success of African bees and the threats they pose have stimulated a tremendous amount of research. The resulting literature forms one of the most detailed descriptions known of the mechanisms that influence invasion success. Several recent reviews of the biology and economic impact of African bees are available $(5,25,51,121,134,135)$. Our review focuses on the ability of African bees to displace European honey bees. Specifically, we concentrate on the genetic composition of the expanding African population and the factors that contribute to the loss of European patrilines and matrilines in invaded regions. We also examine the spread and possible impact of the bee in the United States.

Much controversy has surrounded the terminology used to name and discuss the descendants of $A$. m. scutellata in the New World. The terms Africanized honey bee, African-derived bee, and Neotropical African bee imply different genetic processes, especially with respect to the extent and direction of gene flow between African and European populations $(42,110,120)$. However, we demonstrate in this review that, while some introgression of European alleles has occurred, African genetic and behavioral characteristics have been largely preserved during the invasion process. For brevity, we refer to the descendants of A. m. scutellata in the Americas as African bees. The descendants of introduced European subspecies are referred to as European honey bees. We use the terms Africanized bee and the Africanization process to refer specifically to colonies that arise from European queens mated with African drones.

\section{Honey Bee Biogeography and New World Introductions}

The natural range of $A$. mellifera extends from northern Europe to southern Africa, and from the British Isles to the Ural Mountains, western Iran, and the Arabian peninsula (92). More than 25 subspecies are currently recognized (24), primarily on the basis of morphometric studies (92). Engel (24) brought the nomenclature of honey bee subspecies into line with the international rules of zoological nomenclature, and the subspecies names and authorships presented in that work are used here. 
Study of geographic variation in the mtDNA of honey bees has revealed four geographic lineages of mtDNA mitotypes, or unique sequences, within A. mellifera: west European, east European, African, and Middle Eastern (27, 28, 74, 110, 114). Before humans began large-scale transportation and mixing of A. mellifera populations, the four lineages were probably allopatric in distribution. West European mtDNA is found in western and northern Europe (A. m. mellifera Linnaeus, the European black bee), northern Spain (some A. m. iberiensis Engel), and southern Italy (30). East European mtDNA is found in southeastern European, the eastern Mediterranean, and Anatolian populations, including A. m. carnica Pollmann, A. m. ligustica Spinola, A. m. caucasia Pollmann, and A. m. anatoliaca Maa. The African group of mtDNAs is found north and south of the Sahara and includes A. m. capensis Eschscholtz, A. m. intermissa Maa, A. m. lamarckii Cockerell, A. m. litorea Smith, A. m. monticola Smith, A. m. sahariensis Baldensperger, and A. m. scutellata Lepeletier de Saint Fargeau. A. m. iberiensis in southern Spain carries African mtDNA. Middle Eastern or Oriental mtDNA has been found in bees from extreme southeastern Turkey (74), Lebanon (30), Jordan, and Israel (D.R. Smith, unpublished data).

At least three, and probably all four, mitochondrial lineages have been introduced into the New World. The west European linage, primarily A. m. mellifera, dominated sixteenth through eighteenth century introductions into North and South America $(95,105)$. The east European lineage, primarily A. m. ligustica, A. m. carnica, and A. m. caucasia, dominated subsequent introductions $(94,105)$. North African bees, such as Egyptian A. m. lamarckii were also introduced, and this African mtDNA was present at low frequency in feral North American populations prior to the arrival of the African bee from Latin America $(93,95)$.

African honey bees were introduced into the Neotropics in Brazil. From 1954 to 1955 , beekeeping agencies, government departments, and private beekeeping cooperatives in Brazil initiated projects to increase the low honey production of European (primarily west European A. m. mellifera) colonies kept by commercial beekeepers. A. m. adansonii from southern Africa [now known as A. m. scutellata (48)] was determined to be the best population to introduce. In 1956, W.E. Kerr traveled to Africa to select queens of the best stocks (120). One of six queens collected in Tanganyika and 46 of 132 collected from Pretoria, South Africa, survived introduction into Brazil and formed the nucleus of the population that would eventually colonize much of the Western hemisphere. Human-assisted distribution of A. m. scutellata queens further helped to establish the initial African population in Brazil (120).

The different subspecies of honey bees interbreed to produce viable, fertile offspring. The introduction of A. m. scutellata into Brazil therefore initiated the beginning of a grand, unplanned experiment on the relative fitness of European, African, and African/European hybrid honey bees in the wild, in apiaries, and under a variety of climatic conditions. As the African bee spread throughout Latin America, considerable debate arose over the symmetry of gene flow between African and European subspecies and the extent to which European alleles persisted in 
feral African populations. The need to differentiate between bees of European and African ancestry and to track changes in the genetic composition of invading and resident populations stimulated a large body of research on genetic differences among honey bee races. This work has made it possible to infer ancestry of African populations in the New World, and the gradual expansion of the African population from Brazil to the United States has provided a time series of older to younger feral African populations. In the next section we summarize the results of studies using different techniques to track the genetic composition of honey bee populations in the Americas. Collectively, the studies have shown that $(a)$ there is a high frequency of African mtDNA in feral African populations, in some cases to the near exclusion of European mtDNA; $(b)$ feral African populations may show evidence of paternal gene flow from European sources, but the frequency of European alleles gradually decreases in long-established feral African populations; and (c) the European alleles that persist over time are predominantly of west European rather than east European origin.

Several important variables ideally should be reported in studies of the genetic composition of New World honey bee populations. These are $(a)$ time since the arrival of African bees to the region (years after arrival, or years AA); (b) date of sample collection; (c) season relative to swarming periods of European and African colonies; $(d)$ whether samples are from feral populations, managed apiaries, or hived feral swarms; and $(e)$ the size and genetic composition of the pre-existing honey bee populations. Although few studies present all of the desired background information, most present collection locations, dates, and feral or domesticated status.

\section{Mitochondrial DNA Polymorphisms}

Initial assumptions of unrestricted gene flow between managed European and feral African populations gave rise to the idea that the advancing population in the Neotropics was a "hybrid swarm," in which the primary factor contributing to Africanization was gene flow from African drones into existing European populations $(64,83)$. However, the hybrid-swarm concept was seriously challenged when mtDNA polymorphisms revealed that over $97 \%$ of feral colonies from Brazil, Venezuela, Honduras, and Mexico possessed African mtDNA haplotypes; east European mitotypes were virtually absent. Because honey bee mtDNA is maternally inherited without recombination, this indicated that feral African colonies were matrilineal descendants of African bees, most likely A. m. scutellata $(45,46,117)$. Although European queens in managed colonies were mating with African drones, European-matriline (Africanized) swarms escaping from apiaries were clearly not a major component of the feral African populations in the regions sampled. This suggested that the population expanding northward consisted largely of African matrilines advancing through the dispersal of swarms and also raised the possibility that different genetic processes predominated in managed versus wild populations $(6,7,113)$. Since these initial studies our understanding of paternal and maternal 
gene flow to the feral African population has been refined in two ways: by more precise identification of $A$. $m$. scutellata mtDNA and by examination of populations of different sizes and ages.

Bees of north African and Iberian ancestry, such as Moroccan A. m. intermissa (31), Egyptian A. m. lamarckii (109), and some Spanish A. m. iberiensis (29, 31, 116), were introduced into the New World prior to the arrival of $A$. $m$. scutellata ( 93 , 95). These bees also carry African mtDNA, but initial analysis of mitotypes using six-base restriction enzymes did not distinguish north African from south African mtDNA. Thus, initial estimates of the frequency of south African matrilines in the Neotropics could have been inflated by the inclusion of north African mitotypes. A subsequently developed procedure using four-base restriction enzymes $(31,32$, $65)$ distinguishes north from south African mitotypes $(95,107)$ and has confirmed that the feral African population in the Neotropics contains a high frequency of south African mtDNA and lower frequencies of other mtDNA haplotypes.

If substantial introgression of European mtDNA into feral African populations actually occurs, then the frequency of European mitotypes should be greatest in (a) areas with large European populations, $(b)$ regions where European and African populations have been in contact the longest, and $(c)$ habitats where African and European bees are equally competitive. The Yucatán Peninsula of Mexico has been the site of numerous studies assessing the effects of European population size on the spread and persistence of European haplotypes $(6,7,76-78,80,88)$. Before the African bee arrived in 1985-1986, the Yucatán Peninsula supported one of the highest densities of east European apiaries in the world. The frequencies of east European, west European, and African (presumably originating from Iberian A. . iberiensis) mtDNA were estimated at $90 \%, 5 \%$, and 5\%, respectively (6). By 1998 (12 years AA), the frequency of east European mtDNA in managed colonies had dropped to $19 \%$, whereas west European and African mtDNA had increased to $19 \%$ and $61 \%$, respectively (6). Mitochondrial haplotype frequencies in feral colonies were 0\% east European, 13\% west European, and 87\% African (6).

African populations in Brazil have been in contact with European honey bees since the 1950s and thus have had more time than any other African population in the Americas to accumulate European mtDNA. However, 35 years after the introduction of African bees into Brazil, 100\% of 126 hived feral swarms carried mtDNA characteristic of A. m. scutellata (111).

The displacement of European bees may arise in part from the competitive superiority of African bees in the Neotropics $(42,43,113,127)$. If so, then greater gene flow between the populations should occur in transition zones between tropical and temperate habitats, where the subspecies may be equally competitive. This is suggested by a study of African bees at their southern limit in Argentina, where an apparent hybrid zone exists between predominantly African and European populations $(54,108)$. mtDNA and morphology of feral colonies were screened in northern Argentina, where populations were "African bee saturated"; in southern locations assumed to be "African free"; and in transition zones between the two. The frequency of African mtDNA was $88 \%$ in the northern African populations, 
$15 \%$ in the southern African-free zone, and $71 \%$ in the transition zone. However, $25 \%$ of colonies from the transition zone showed discordant results, i.e., African morphology with east or west European mtDNA or vice versa, which suggests interbreeding and backcrossing between Europeans and Africans in this transitional habitat. Similar results have been obtained recently for honey bee populations in Peru, where African morphotypes and mitotypes predominate in lower-elevation tropical regions, with a possible hybrid zone occurring in the higher elevations of the Andes Mountains (81a).

Thus, even in areas where hybridization and introgression of European genes have been particularly likely, European mitotypes have dropped to low frequencies, especially in the feral population. European mtDNA has not introgressed deeply in the African populations except at the geographic limits of the African bee's range in South America. Indeed, European mtDNA rarely occurs at frequencies greater than 20\%, and most European mitotypes that persist over time are of west rather than east European origin.

Although mtDNA is an excellent tool for tracing maternal ancestry, it cannot assess paternal contributions to the history and pattern of gene flow. Nuclear markers are necessary to complete the picture of the genetic composition of African populations.

\section{Allozymes}

Although there are no fixed allelic differences between African and European honey bees, two enzyme loci, cytoplasmic malate dehydrogenase (MDH1, E.C. number 1.1.1.37) and hexokinase (HK, E.C. number 2.7.1.1), show substantial allele frequency differences among bees of west European, east European, and African lineages (110). More than five MDH1 alleles are known, but only three are common: $M d h 1^{80}$ (or medium), $M d h 1^{100}$ (or fast), and $M d h 1^{65}$ (or slow). In the Old World, west European populations exhibit high frequencies of $M d h 1^{80}$ ranging from 0.85 to 1.00. African bees show frequencies of $M d h 1^{100}$ ranging from 0.95 to 1.00. Bees of the east European lineage show more regional variation. In A. m. ligustica from northern Italy, the frequency of $M d h 1^{65}$ is high, $M d h 1^{100}$ is moderate to low, and $M d h 1^{80}$ is very low. However, A. m. caucasia and A. m. anatoliaca have east European mtDNA and frequencies of $M d h 1^{100}$ approaching 1.00, similar to those of African bees. Two alleles of HK are known, $H k^{100}$ and $H k^{87}$. $H k^{87}$ occurs in south African bees at frequencies up to 0.70 and is also present at low frequency in A. m. anatoliaca with east European mtDNA, but it is apparently absent in populations with west European mtDNA and the majority of populations with east European mtDNA (110).

Three studies $(19,57,58)$ used allozyme data and racial admixture models to estimate the contributions of A. m. scutellata, A. m. ligustica, and A. m. mellifera to feral African populations in Brazil, Uruguay, and Central America. All three found that $(a)$ the contribution of $A$. $m$. scutellata to the feral population was high, (b) there was low but significant admixture with European bees, $(c)$ there was more admixture with European bees near the northern and southern limits of the 
feral African populations, and $(d)$ most European admixture was from the west European A. m. mellifera and not from the east European A. m. ligustica. Similar results were seen in 126 hived, feral African swarms collected in Brazil 35 years after the introduction of A. m. scutellata (111). All were classified Africanized by morphometric techniques and mtDNA. The frequency of alleles typical of A. $m$. scutellata ranged from 0.79 to 0.84 for $M d h 1^{100}$ and from 0.54 to 0.60 for $H k^{87}$. Admixture from west European bees was suggested by the presence of $M d h 1^{80}$ at frequencies of 0.12 to 0.15 . The presence of $M d h l^{65}$ at frequencies of 0.04 to 0.07 indicated a small contribution from A. m. ligustica or other east European stock. However, with only two commonly utilized loci, neither showing fixed differences between European and African bees, allozymes provide only limited information about the extent of gene flow between European and African bees. Additional nuclear markers have been employed to provide a finer-grained picture of the genetic composition of African populations.

\section{Randomly Amplified Polymorphic DNA}

Suazo et al. (125) used 700 randomly amplified polymorphic DNA (RAPD) primers to screen African A. m. scutellata, European A. m. ligustica, A. m. carnica, A. m. mellifera and A. m. iberiensis, and African and European bees from the New World. African populations from Latin America were represented by 28 feral swarms and managed colonies originating as hived feral swarms collected from Mexico in 1988 (approximately one year AA) and from Honduras in 1991 (approximately six years AA), all with African mtDNA. An east European-specific RAPD marker was present in 100\% of A. m. ligustica sampled, 53\% of New World European bees, and absent in African bees in Latin America. On the other hand, African markers were present at lower frequency in African populations in the Neotropics than in south African A. m. scutellata. Specifically, a marker present in $83 \%$ of south African A. m. scutellata worker samples was found in only $39 \%$ of African workers in Latin America, and a marker present in 50\% of south African A. $m$. scutellata workers was present in $41 \%$ of New World African workers. The authors suggested that this was due to hybridization with European bees. However, two factors complicate the interpretation of these data: Colonies from populations one and six years after arrival of African bees were pooled, and contributions from west and east European bees were combined. In addition, founder effects stemming from the small initial number of introduced A. m. scutellata colonies cannot be discounted.

\section{Nuclear Restriction Fragment-Length Polymorphisms}

Nuclear restriction fragment-length polymorphisms (RFLPs) have been particularly useful for elucidating the genetic composition of African populations in the Americas. Digestion of genomic DNA with the restriction enzymes MspI and DdeI and probing with anonymous DNA fragments from a honey bee genomic library revealed a locus (locus 178) with 68 alleles, which appear to be nearly or completely discontinuous in their distribution among Old World lineages $(44,61)$. In 
a study of feral Mexican colonies approximately one year AA, the proportions of alleles detected were 38\% west European and 62\% east European among drones with east European mtDNA, and 31\% west European, $8 \%$ east European, and $61 \%$ African among drones with African mtDNA. In comparison, in a Honduran population 5-7 years AA, the proportions of alleles among drones with African mtDNA were 26\% west European, 3\% east European, and 72\% African.

More recent studies [(122-124); A. Suazo \& H.G. Hall, manuscript submitted] employed 8 loci and 12 locus + restriction enzyme combinations to examine the frequency of African, west European, and east European alleles in populations from Mexico (19 colonies collected in 1988, 1 year AA), Honduras (31 colonies collected in 1989, 4 years AA), Costa Rica (14 colonies collected in 1989, 6 years AA), and Venezuela (19 colonies collected in 1988, 11 years AA) and in nonAfrican populations from the United States. Seventeen alleles were found to be typical of African honey bees, 11 of east European honey bees, and 5 of west European honey bees.

The collective frequency of African alleles in these four New World African populations was not significantly different from that of south African A. m. scutellata, although the frequencies of African alleles increased slightly from north to south (or from younger to older African populations). The frequency of east European alleles was low in all four populations and decreased from $23 \%$ in the north to $4 \%$ in the south. In contrast, the frequency of west European alleles remained relatively constant $(16 \%-28 \%)$ and did not differ significantly among the four African populations from the Neotropics.

\section{Microsatellite DNA Polymorphisms}

A final study of the invasion of the Yucatán peninsula of Mexico employed six microsatellite loci and mtDNA haplotypes (7). Reference samples were drawn from Old World populations of the east European, west European, and African lineages, from 20-21 colonies collected from Yucatán apiaries in 1985 (before arrival of African bees), and from 28 colonies of African bees from Venezuela. The pre-Africanized Yucatán sample was essentially east European. On the basis of microsatellite allele frequencies in the Old World reference samples, 17 colonies had European nuclear genomes and European mtDNA, 1 colony had a European nuclear genome and north African mtDNA, and 1 colony had a hybrid nuclear genome and European mtDNA (7). The European mitotypes included 18 east European and 1 west European (6). The Venezuelan reference population was primarily African and west European. Twelve colonies had an African nuclear genome and African mtDNA, 15 colonies had an African/west European hybrid nuclear genome and African mtDNA, and 1 colony had an African/west European hybrid nuclear genome and European (possibly east European) mtDNA (6).

In 1998 (13 years AA) a new set of samples was collected from the Yucatán. This included 312 colonies maintained in apiaries and 31 feral colonies. On the basis of a comparison with allele frequencies in the Venezuelan and Yucatan reference samples, 219 apiary colonies had nuclear genomes similar to those Venezuelan African 
bees (i.e., African and African/west European hybrids), of which approximately $65 \%$ had African mtDNA and 35\% had east or west European mtDNA. Another 89 apiary colonies had nuclear genomes intermediate between the European-like Yucatán 1985 and Venezuelan reference samples, approximately 55\% with east or west European mtDNA and 45\% with African mtDNA. Only four colonies had nuclear genomes similar to the Yucatán 1985 (i.e., east European) genomes, one with European mtDNA and three with African mtDNA. The authors did not report which nuclear genomes were associated with east and west European mtDNA, but they did note that 64 colonies (19.3\%) had east European mtDNA, 64 had west European mtDNA, and the remainder (61.3\%) had African mtDNA (6).

The 31 feral colonies collected in 1998 showed more extreme shifts in genetic composition. Twenty colonies had nuclear genomes similar to those of Venezuelan African bees, 18 with African mtDNA and 2 with west European mtDNA. The remaining 11 colonies had nuclear genomes intermediate between those of preAfricanized Yucatán and Venezuelan bees, 9 with African mtDNA and 2 with west European mtDNA.

In summary, the majority of research reveals a consistent pattern for changes in the genetic composition of honey bee populations in the Neotropics. When African bees first expand into a new location, both east and west European nuclear and mitochondrial markers are found in the feral population, along with African markers. However, within 5-10 years, African nuclear and mitochondrial genetic markers predominate and the frequency of east European markers typically decreases to less than $10 \%$, although the extent to which they persist can exhibit geographic and temporal variation. West European markers behave quite differently. Their frequency remains relatively constant at 16\%-30\% throughout the range of the African bee in the Americas, which suggests that these markers have not been accumulating gradually as the population expanded northward. Instead, west European nuclear and mitochondrial markers may have entered the African population during the initial introduction into Brazil and have been "carried along" during the invasion process. Nevertheless, the collective frequency of all European alleles rarely exceeds $30 \%-35 \%$, even in regions where prolonged contact between the races or large aggregations of managed European colonies make hybridization especially likely. Although the African bees in the Neotropics are no longer genetically identical to the honey bees of southern Africa, they have largely retained the genome of A. m. scutellata despite almost 50 years of contact with European bees.

\section{FACTORS CONTRIBUTING TO THE PRESERVATION OF AFRICAN CHARACTERISTICS}

No single factor is responsible for the displacement of European characters in invaded areas. Rather, the retention of African traits arises from a combination of at least six different mechanisms that contribute to the loss of European patrilines and matrilines. The relative importance of each mechanism may differ between 
managed and feral settings. In commercial apiaries where European matrilines are maintained by requeening, factors contributing to the introgression of African paternal alleles may be the major determinants for the loss of European traits $(6$, $7,43,67,81,125,126)$. In contrast, the retention of African characteristics in feral populations may be shaped more by the loss of European matrilines $(6,7,42,43$, $77,113)$. Whether colonies are managed or feral, the biological and behavioral factors described below are responsible for making the African honey bee such a successful invader and may provide guidelines for assessing the potential for invasion by other introduced species, especially social insects.

\section{Colony Growth and Swarming Rates}

A major factor contributing to the abundance of African matrilines in feral populations is the faster growth rate of African colonies. Compared with European colonies, African colonies have a greater emphasis on pollen collection $(26,72)$, have a more rapid conversion of pollen into brood $(101,119)$, and devote two to four times as much comb area to brood rearing $(62,63)$. The resulting higher growth rates allow for increased African swarm production. In the Neotropics, African colonies can increase 16-fold per year, whereas maximum increases in feral European colonies in temperate areas are only three- to sixfold $(70,134)$. Consequently, the density of African colonies in the New World can increase quickly and cause an overrepresentation of African mitotypes, especially in regions with small European populations $(6,91,118)$. However, colony density alone cannot fully account for the displacement of European matrilines, because African haplotypes become predominant over time, even in areas with large European populations $(6,7,43,60)$.

\section{Negative Heterosis in Hybrid Bees}

A factor proposed repeatedly to explain the loss of European alleles is reduced fitness of hybrid bees $(6,42,45,117)$. In particular, genetic incompatibilities between European maternal and African paternal alleles often have been suggested to explain the drastic reduction in European mitotypes in the feral population, despite repeated opportunities for Africanized hybrid swarms to move from commercial apiaries into the wild $(43,44,67,126,127)$.

Hybrid workers have mass-specific metabolic rates that are lower than those of African bees and as low as or lower than those of European bees (47). This has contributed to speculation that hybrids could be less fit than parentals, perhaps because of the disruption of coadapted enzyme complexes that might affect flight performance and colony dispersal ability. In addition, hybrids with European maternity have lower metabolic rates than those with African maternity, which may reflect nuclear/cytoplasmic incompatibilities that put European-matriline hybrids at a particular disadvantage. Similarly, hybrid workers exhibit greater fluctuating asymmetry (FA) for wing shape compared to African bees, even when reared in the same hive environments (99a). FA is defined as the variation in small, random differences that occur between left- and right-side structures in bilaterally symmetrical organisms. Because FA results from the inability of developmental programs 
to resist perturbations, it is assumed to be negatively correlated with developmental stability and fitness (73). Hybridization can increase FA, perhaps through the disruption of coadapted gene complexes (115). It has therefore been proposed that hybridization between temperate-climate European bees and tropically adapted African bees results in reduced developmental stability that is expressed as greater FA for wing shape (99a). Hybrids have also been suggested to be less efficient foragers (77) and to have lower rates of brood production and honey storage $(126,127)$, all of which could contribute to the loss of European-matriline hybrid colonies.

Despite the possible influence of negative heterosis on worker viability and colony survival, the importance of hybrid inferiority remains one of the more controversial aspects of the African bee invasion (7, 56, 78, 87, 88, 99a, 108). The presence of European genetic markers in the feral population of recently invaded areas $(80,81,87,88,106)$ and their persistence at low levels over time in several regions $(6,7,56,108,111)$ have been interpreted as evidence that there are no genetic incompatibilities of significance between the races. However, the presence of European alleles a few years after a colonization event may not predict long-term genetic changes $(43,126)$. Also, the European markers that persist 30 or more years after invasion could represent selectively neutral alleles that have "hitchhiked" with advantageous African traits $(22,58)$ and may reflect little about the selective mechanisms that have shaped population genetic structure (43). Resolving the importance of negative heterosis in the spread of African bees will require long-term studies of the survival and reproduction of African- and European-matriline hybrid colonies maintained in the same habitat.

\section{Mating Advantages for African D rones}

When African bees colonize areas with resident European populations, queens mate disproportionately with African drones, which results in the rapid displacement of European patrilines in managed and feral colonies. A major component of this phenomenon is the numerical superiority of African drones, which arises from (a) proportionately greater drone production by African colonies than by European colonies (71, 85); (b) African drones moving into and being maintained by European colonies, which may suppress the production of European drones (86); and (c) high rates of queen loss in African colonies $(62,70)$, which results in queenless colonies that rear large numbers of worker-produced drones (15, 136). Other factors may also contribute to an African mating advantage, including (a) seasonal patterns of drone production that favor queens mating primarily with African drones during certain times of the year $(23,79),(b)$ mating-flight characteristics that promote mating between European queens and African drones but decrease the chance of reciprocal mating (126), and (c) the possible use of African spermatozoa at higher rates by queens mated to both African and European drones (17). In combination, these factors may favor the introgression of African paternal alleles into European colonies while resulting in relatively little introgression of European paternal markers into African colonies. However, our understanding of honey bee mating biology and sperm physiology are too limited to determine 
whether African drones have a mating advantage over European drones when both are present in equal numbers in mating areas. Indeed, other than numerical superiority, no factor has been conclusively demonstrated to convey a mating advantage for African drones.

\section{African-Patriline Advantages D uring Queen Replacement}

European patrilines may be lost when colonies in invaded regions raise new queens. During queen replacement, workers rear multiple virgin queens (VQs) in specially constructed queen cells. Emerged VQs destroy their rivals still in queen cells and kill one another until there is a sole survivor that inherits the natal nest (103). When African bees invade an area, queens mate with a combination of African and European drones, which results in colonies composed of African- and Europeanpatriline workers. During queen replacement, these colonies will rear VQs from both patrilines, but those with African paternity may have a competitive advantage $(43,126)$.

African-patriline VQs develop faster and emerge sooner than European-patriline queens, which may give them more opportunities to eliminate rivals confined in queen cells $(16,18,97,98)$. In European-matriline colonies, emerged Africanpatriline VQs kill more rivals than their European-paternity sister queens and produce more bouts of "piping," which consists of a series of pulsed notes that may inhibit the emergence of rivals and enhance fighting success $(98,103)$. Workers preferentially perform "vibration signals" on African-patriline VQs, which may promote queen survival and further contribute to an African-patriline advantage $(98,103)$. However, the role of worker preferences in queen replacement and the spread of African alleles is poorly understood $(97,98)$.

In combination, the faster development time, increased fighting ability, greater piping behavior, and higher rates of vibration signal activity may result in Africanpatriline VQs having a greater likelihood of becoming the new laying queens of their colonies $(18,97,98)$. Because these VQs will mate disproportionately with African drones, there will be an increasing introgression of African paternal alleles over consecutive queen replacement events. An African-patriline advantage for queens may therefore promote the Africanization of managed European colonies and act as a barrier to the introgression of European paternal alleles into African colonies. However, most studies that have examined queen success have utilized hybrid colonies containing only two patrilines and cuticular color markers to distinguish African from European queens $(18,97,98)$. These methods might influence queen behavior and worker-queen interactions (4). Studies using molecular markers and colonies with a normal genetic composition are needed before definite conclusions can be drawn about an African advantage during queen replacement.

\section{Dominance of African Alleles}

Honey bee colonies in the Neotropics often exhibit African behavioral traits, even in areas where relatively high proportions of European alleles persist (77, 81, 87, 
$88,111)$. African alleles may therefore be dominant for some characters. Although dominance would not necessarily result in the loss of European genetic markers, it would contribute to the preservation of the African phenotype.

African alleles may be dominant for certain aspects of foraging $(26,99)$, queen behavior (98), and resistance to the parasitic mite Varroa destructor (40). Dominance associated with African alleles has been most thoroughly examined for defensive behavior. African honey bees show stronger defense responses than European bees do $(35,52)$ and many aspects of defensiveness may be genetically determined (3). Colonies composed of hybrid workers that arise from European queens mated to New World African drones show levels of defensiveness that do not differ from those of African bees $(13,33,35,52)$. Colonies arising from New World African queens mated to European drones show decreased defense responses, although their defensiveness is still significantly greater than that of European colonies (13). These results suggest that African traits for defensiveness are genetically dominant and that stinging behavior is more influenced by paternal than by maternal factors. Because honey bee queens mate with up to 17 different drones (69), colony-level defensive responses may depend on the relative abundance of African patrilines in the worker population $(13,35)$. However, there are often genotype-by-colony environment interactions, such that genetic dominance alone cannot account fully for worker defensive responses (3) or perhaps other aspects of African honey bee behavior (38).

\section{Nest Usurpation}

Nest usurpation is a form of social reproductive parasitism in which small African swarms invade European colonies, replace the resident queens, and cause the complete and instantaneous loss of European matrilines. Annual usurpation rates have been reported at 5\% in Venezuela (8) and $0 \%-40 \%$ in different regions of Mexico (129). In southern Arizona, annual usurpation rates can reach 10\%25\% (G. DeGrandi-Hoffman, unpublished data). Nest usurpation has therefore been speculated to play an important but regionally variable role in the spread of African bees in Latin America $(6,7,43)$ and may contribute to the loss of European matrilines in the United States.

It is unclear how African swarms find and invade host colonies. Pheromonal cues associated with the condition of a colony and the presence of a queen may be involved in the location of susceptible hosts, because usurpation swarms often invade European colonies, particularly those that are queenless or have a caged queen $(8,21,129)$. However, queenright colonies can also be invaded, which suggests that additional cues are involved in host location $(8,129)$. Although some overt aggression occurs during the invasion process, it is possible that pheromonal signals also help usurpation swarms gain entry into host colonies and contribute to the loss of resident queens. However, the mechanisms that regulate nest usurpation remain some of the least understood aspects of the African bee invasion process and have received virtually no systematic study. 


\section{THE AFRICAN HONEY BEE IN THE UNITED STATES}

The African bee arrived in south Texas in 1990 (53) and in the intervening 13 years has spread throughout Texas, New Mexico, and Arizona and is currently colonizing southern California and the central valleys (133). As has occurred in Latin America, the African bee appears to be displacing feral European colonies (especially east European colonies) in the southwestern United States $[(59,60)$; A. Suazo \& H.G. Hall, manuscript submitted]. However, the rate of spread in the United States is often much less than the $160-500 \mathrm{~km}$ per year reported for the Neotropics $(5,96,127)$. Also, the pattern of spread has been more erratic, and as of 2003 the African bee has not yet become established in the southeastern states (132). The factors influencing these distribution patterns are of considerable interest because they will largely determine the ultimate range of the bee in the United States and its economic impact.

\section{Spread and Range Expansion}

At least five interacting factors may contribute to the slower, more erratic spread of the African bee in North America. First, African bees may have a reduced capacity for winter survival $(127,130,131)$, which might confine them to the southern regions of the United States. The northward range of the bee is predicted to extend to around $34^{\circ} \mathrm{N}$ latitude, similar to the latitudinal limits in South America, with a seasonal ebb and flow of colonies into adjacent colder regions $(5,133)$. However, the ability of African bees to survive extended periods of cold is unclear $(20,81 \mathrm{a}$, 131) and cannot account fully for the failure to establish in the southeastern states (132). Rainfall may also influence range expansion. A. m. scutellata may be more adapted to arid habitats (92) and few African colonies have been reported from areas in the southwest United States that receive more than $135 \mathrm{~cm}$ of rain per year, despite temperature regimes that should favor colonization (132). The failure of the African bee to spread into the southeastern United States may therefore result from a combination of rainfall and temperature, although it is unclear how the interaction of these climatic factors will shape the ultimate distribution of the bee in North America.

Second, expansion patterns may be influenced by photoperiod. Seasonal patterns of colony growth and reproduction for European bees are tightly linked to changes in day length. In contrast, because the availability of pollen and nectar in tropical habitats often bears little relation to photoperiod, African colonies have evolved annual cycles that are geared more directly to changes in rainfall and floral abundance $(87,100,134)$. This in turn might make African bees less adapted to temperate climate conditions and could compromise their survival as they expand northward.

Third, numerous authors have speculated that the rate and patterns of colonization will be influenced by the size of the preexisting European honey bee population $(83,87,91,133)$. A huge number of managed and feral European colonies in the 
United States are expected to create levels of competition and interbreeding that slow the spread of African bees and increase the introgression of European alleles, especially in more northern latitudes where tropically adapted traits may be less advantageous and hybridization may increase survival $(7,76)$. However, high European colony densities have had little mitigating effects on the colonizing ability of African bees in the Yucatán Peninsula, northern Mexico, or southern Texas $(7,91)$. The African bee is now spreading rapidly through the central valleys of California despite contact with large managed European populations $(67,68)$. At present, it is unclear to what extent existing managed and feral European populations will shape the range of African bees in the more northern regions of the United States (5).

Fourth, a major factor that may influence the expansion of African bees in North America is parasitism by the tracheal mite, Acarapis woodi, and the varroa mite Varroa destructor. The initial slow rate of spread in southern California was attributed in part to negative effects of varroa mites on African colonies (133). However, African bees may be more resistant to varroa than European bees $(1,41,89,128)$ and may also have greater resistance to tracheal mites (12). Tracheal and varroa mites have decimated feral European populations throughout the United States and resulted in the loss of up to $50 \%$ of managed colonies $(55,59,60)$. Yet, African bees have become established in many areas of the southwest once dominated by European bees despite the continued presence of mites $(59,67)$. The degree to which African bees tolerate varroa mites in the United States is unclear. Resistance is influenced by climate and the genetic strains of mites and bees in different areas and is more strongly expressed in Central and South America than in Mexico and the southern United States (14, $40,90,128)$. Nevertheless, the available evidence suggests that, although parasitic mites may slow the rate of spread and population increase by African bees in the United States, they are unlikely to prevent colonization in areas with favorable temperature and rainfall regimes. Indeed, the elimination of feral European colonies by mites will reduce competition for forage and nest sites, diminish the chances for hybridization between African and European bees, and thus may enhance the establishment and spread of African populations in North America $(5,40,55,127)$.

Finally, the rate and patterns of spread of African bees in North America may be strongly influenced by migratory beekeeping practices. Unlike other countries where African bees have invaded, the United States has a highly mobile beekeeping industry. Every year more than a million colonies are moved throughout the United States for overwintering or to pollinate crops $(5,66)$. If a colony loses its queen during transport and requeens itself in a region where there are African drones, it will become Africanized. Also, queenless colonies may be more susceptible to invasions by African swarms (129). Consequently, the transportation of colonies from areas with a feral African population back into apiaries in other parts of the United States could accelerate the spread of African patrilines and matrilines and move them past natural barriers that might otherwise slow or stop their progression (5). 
However, at present the repercussions of migratory beekeeping on the spread of African bees have not been fully realized.

\section{Economic Impacts}

To date, the economic impact of the African bee on U.S. agriculture has been less severe than initially predicted, perhaps because of the slower rate of spread, reduced fitness in temperate climates, and a high level of preparedness based on the experiences of Latin America. However, it is difficult to evaluate the impact of the African bee per se because its effects within a given region have been confounded by mite-induced losses of managed colonies and the seasonal importation of large numbers of European colonies for pollination purposes. Nevertheless, the major negative influence of the African bee is expected to occur through its effects on beekeeping activities related to pollination. Exactly how these effects are manifested will depend on the degree to which European traits can be maintained in colonized areas and the extent to which African bees can be integrated into U.S. agricultural practices.

The most commonly recommended management practice for maintaining European characteristics in invaded areas is the annual requeening of colonies with European queens that have been mated in "African-free zones." However, reliance on requeening may become problematic in areas that develop an increasingly African feral population. If colonies supersede introduced European queens, they will rear VQs that mate with both African and European drones. The resulting Africanized colonies can become recalcitrant to further requeening attempts (G. DeGrandi-Hoffman, unpublished data) and may produce African-patriline queens if subsequent queen replacement events are not controlled (98). Because of the dominance of African alleles for defensiveness $(33,35,52)$, first generation hybrids may not differ from African bees in their stinging responses and are often considered unacceptable for commercial use (37). Management practices can result in levels of defensiveness similar to that of European bees, even if queens are allowed to mate naturally in areas where African bees have migrated (39). These programs require continued selection for gentle colonies, the elimination of feral African colonies, and the maintenance of high densities of European drones to ensure that no more than $25 \%$ of matings involve African drones $(9,34,37)$. The continued reliance on annual requeening as a regulatory measure may therefore require a degree of control over queen replacement and mating that could become increasingly impractical in some areas $(5,34,37)$.

The integration of African honey bees into current U.S. agricultural practices is generally considered unworkable. However, African bees have been successfully integrated into agricultural practices in several regions of Latin America $(36,82)$ and may be superior to European bees for the pollination of certain crops (2). The possible resistance of African bees to mites and some bacterial diseases $(1,12,82)$ and their reduced susceptibility to certain pesticides (11) may also favor their incorporation into agriculture. However, utilizing African colonies involves substantial modifications to beekeeping practices and annual 
requeening with European queens is still considered necessary to ameliorate undesirable African characteristics (82). It is unlikely that African colonies can be incorporated into the migratory beekeeping practices of the United States. The manipulation and transport of colonies for pollination can cause increased stinging and queen loss in African colonies (10). Liability costs that may arise from the movement of African bees may further hinder their suitability for U.S. beekeeping.

In summary, it is not possible to predict the geographic range and impact of the African bee in the United States at this time. The rate of expansion probably will be slower and the persistence of European traits may increase as the bee moves northward. However, the ultimate distribution may depend as much upon human-assisted movements as upon the bee's inherent ability to disperse and thrive in temperate climates. The available evidence suggests that the factors that have favored the retention of the African genome in Latin America will also contribute to a predominance of the African bee throughout the southwestern states. The eventual economic impacts of the African bee in colonized areas will depend upon the ability to maintain migratory beekeeping practices and preserve European stocks in the face of a growing feral African population and mite-induced losses of European colonies.

\section{FUTURE DIRECTIONS}

Although a huge body of literature has been amassed on the spread of the African bee in the New World, many questions remain about this remarkably successful biological invasion. In the final section of our review, we identify the issues that we feel are most important for understanding fully the invasion process and the possible impact of the bee in the United States.

A major puzzle in the African bee invasion is the differential persistence of west versus east European alleles in the feral population and the extent to which this phenomenon will continue as the African bee colonizes North America. The greater persistence of west European alleles may be related to the question of hybrid inferiority. West European alleles may be more compatible than east European alleles with a mostly African genome or may confer some advantage in particular habitats. Alternatively, the west European markers that persist in the New World may represent neutral alleles that introgressed early in the invasion process in Brazil and may have only minor effects on the behavior and biology of the African population $(43,44)$. The persistence of west versus east European alleles therefore offers an excellent opportunity to assess the importance of negative heterosis in the invasion process. Studies are needed that examine the long-term survival and success of colonies of known African and European maternal and paternal genetic composition that are maintained in the same foraging environments in the United States.

With respect to the mechanisms that influence the loss of European traits, future research should focus on the advantages experienced by African reproductives. 
To evaluate fully the importance of colony density and African mating advantages in the displacement of European bees, we need more complete information on feral population distributions and seasonal patterns of swarming, dispersal, and drone production in invaded regions. Also, research is needed on the physiology and competitive ability of African and European sperm to assess the possibility of African sperm precedence. Further studies of queen replacement are necessary to evaluate possible worker preferences for African-patriline queens and how such preferences could act as barriers to gene flow. Of particular importance is the need to understand the mechanisms that regulate the usurpation of European colonies by African swarms and the role that reproductive parasitism may play in the spread of African matrilines in North America.

With respect to the African invasion process in the United States, perhaps the most intriguing question is why the bee has failed to establish in the southeastern states. Studies conducted in transition zones, such as in east Texas, may be particularly instructive for unraveling the biotic and abiotic factors that determine colony dispersal patterns and the relative abundance of African and European alleles in feral populations. Assessing the range and economic impact of African bees in the United States will require studies of the effects of migratory beekeeping and other agricultural practices that could expedite the spread of this invasive insect.

In conclusion, the ability of the African bee to colonize the Americas has involved a complex interaction of population dynamics, genetic phenomena, and physiological and behavioral mechanisms. In addition to factors that directly increase survival and reproductive success, the invasion by African honey bees has involved more subtle mechanisms (e.g., differences in queen developmental time, worker-queen interactions, and reproductive parasitism) that may contribute to asymmetrical gene flow and promote the prevalence of African bees in habitats formerly dominated by European bees. The success of African bees demonstrates the role that humans play in the spread of nonindigenous species, through the direct movement of introduced organisms and possible selection pressures that human enterprises might exert on native and nonnative populations.

The African bee invasion also underscores the difficulty in predicting the scale at which nonnative species can invade and establish in various habitats. The African bee colonized 17 countries over two continents within 50 years of introduction. Surely the magnitude of this spread and the effects on agriculture and society were never imagined when the program to improve honey production in Brazil was initially developed. The introduction of any nonindigenous species is now often a subject of intense debate, because it is so difficult to make definitive assessments of the environmental and economic impacts a foreign species may have. Although the African honey bee adds another case against the importation of nonindigenous species, it also provides a valuable framework for identifying biological attributes that might be incorporated into the decision-making process for future introductions and the control of nonnative organisms. 


\section{ACKNOWLEDGMENTS}

We thank M. Spivak, H.G. Hall, and O.R. Taylor for valuable comments on the manuscript. We give special thanks to A. Suazo and H.G. Hall for sharing their submitted manuscripts. Research funding was provided by the National Science Foundation, the U.S. Department of Agriculture, the Whitehall Foundation, and the Fulbright Scholarship Program.

\section{The Annual Review of Entomology is online at http://ento.annualreviews.org}

\section{LITERATURE CITED}

1. Arechavaleta-Velasco JE, Guzmán-Novoa E. 2002. Relative contribution of four mechanisms to the resistance of honey bees Apis mellifera $\mathrm{L}$. against the mite Varroa jacobsoni Oud. See Ref. 25, pp. 197-202

2. Basualdo M, Bedascarrasbure E, De Jong D. 2000. Africanized honey bees (Hymenoptera: Apidae) have a greater fidelity to sunflowers than European bees. J. Econ. Entomol. 93:304-307

3. Breed MD, Guzmán-Novoa E, Hunt GJ. 2004. Defensive behavior of honey bees: organization, genetics, and comparisons with other social insects. Ann. Rev. Entomol. 49:271-98

4. Breed MD, Welch CK, Cruz R. 1994. Kin discrimination within honey bee (Apis mellifera) colonies: an analysis of the evidence. Behav. Process. 33:25-40

5. Caron DM. 2001. Africanized Bees in the Americas. Medina, OH: Root

6. Clarke KE, Oldroyd BP, Qeuzada-Euán G, Rinderer TE. 2001. Origin of honey bees (Apis mellifera L.) from the Yucatan peninsula inferred from mitochondrial DNA analysis. Mol. Ecol. 10:134755

7. Clarke KE, Rinderer TE, Franck $P$, Quezada-Euán JG, Oldroyd BP. 2002. The Africanization of honey bees (Apis mellifera L.) of the Yucatan: a study of a massive hybridization event across time. Evolution 56:1462-74

8. Danka RG, Hellmich RL, Rinderer TE.
1992. Nest usurpation, supersedure and colony failure contribute to Africanization of commercially managed European honey bees in Venezuela. J. Apic. Res. 31:119-23

9. Danka RG, Loper GM, Villa JD, Williams JL, Sugden EA, et al. 1994. Abating feral Africanized honey bees (Apis mellifera L.) to enhance mating control of European queens. Apidologie 25:520-29

10. Danka RG, Rinderer TE, Collins AM, Hellmich RL II. 1987. Responses of Africanized honey bees (Hymenoptera: Apidae) to pollination-management stress. $J$. Econ. Entomol. 80:621-24

11. Danka RG, Rinderer TE, Hellmich RL II, Collins AM. 1986. Comparative toxicities of four topically applied insecticides to Africanized and European honey bees (Hymenoptera: Apidae). J. Econ. Entomol. 79:18-21

12. Danka RG, Villa JD. 1996. Comparative susceptibility of Africanized honey bees from South Texas to infestation by Acarapis woodi. Southwest. Entomol. 21:45156

13. DeGrandi-Hoffman G, Collins A, Martin JH, Schmidt JO, Spangler HG. 1998. Nest defense behavior in colonies from crosses between Africanized and European honey bees (Apis mellifera L.). J. Insect Behav. 11:37-45

14. de Guzman LI, Rinderer TE, Collins A, Lancaster VA. 2002. Attractiveness of Africanized honey bee brood from 
southern Texas to Varroa destructor infestation. Am. Bee J. 142:130-32

15. DeGrandi-Hoffman G, Schneider SS. 2002. Worker behaviors in queenless Africanized honey bee colonies. See Ref. 25, pp. 104-8

16. DeGrandi-Hoffman G, Spivak M, Martin JH. 1993. Role of thermoregulation by nestmates on the development time of honey bee (Hymenoptera: Apidae) queens. Ann. Entomol. Soc. Am. 86:165-72

17. DeGrandi-Hoffman G, Tarpy DR, Schneider SS. 2003. Patriline composition of worker populations in honey bee (Apis mellifera L.) colonies headed by queens inseminated with semen from African and European drones. Apidologie 34:111-20

18. DeGrandi-Hoffman G, Watkins JC, Collins AM, Loper GM, Martin JH, et al. 1998. Queen developmental time as a factor in the Africanization of European honey bee (Hymenoptera: Apidae) populations. Ann. Entomol. Soc. Am. 91:52-58

19. Del Lama MA, Lobo JA, Soares AEE, Del Lama SN. 1990. Genetic differentiation estimated by isozymic analysis of Africanized honey bee populations from Brazil and from Central America. Apidologie 21:271-80

20. Dietz A, Krell R, Pettis J. 1986. Study of winter survival of Africanized and European honey bees in San Juan, Argentina. Proc. Africanized Honey Bee Symp., pp. 87-91. Park Ridge, IL: Am. Farm Bureau Res. Found.

21. Dietz A, Vergara C, Mejia M, Krell R. 1989. Forced queen usurpation in colonies of Africanized and European honey bees in Argentina. Proc. XXXII Apimondia Int. Congr., Rio de Janeiro, Brazil, pp. 88-92. Bucharest, Rom.: Apimondia Publ.

22. Diniz-Filho JAF, Malaspina O. 1995. Evolution and population structure of Africanized honey bees in Brazil: evidence from spatial analysis of morphometric data. Evolution 49:1172-79

23. Echazarreta CM, Paxton RJ. 1997. Comparative colony development of African- ized and European honey bees (Apis mellifera) in lowland Neotropical Yucatan, Mexico. J. Apic. Res. 36:89-103

24. Engel MS. 1999. The taxonomy of recent and fossil honey bees (Hymenoptera: Apidae; Apis). J. Hym. Res. 8:165-96

25. Erickson E, Page RE Jr, Hanna AA, eds. 2002. Proceedings of the 2nd International Conference on Africanized Honey Bees and Bee Mites. Medina, $\mathrm{OH}$ : Root

26. Fewell JH, Bertram SM. 2002. Evidence for genetic variation in worker task performance by African and European honey bees. Behav. Ecol. Sociobiol. 52:31825

27. Franck P, Garnery L, Celebrano G, Solignac M, Cornuet J-M. 2000. Hybrid origins of honey bees from Italy (Apis mellifera ligustica) and Sicily (A. m. sicula). Mol. Ecol. 9:907-21

28. Franck P, Garnery L, Loiseau A, Oldroyd BP, Hepburn HR, et al. 2001. Genetic diversity of the honey bee in Africa: microsatellite and mitochondrial data. Heredity 86:420-30

29. Franck P, Garnery L, Solignac M, Cornuet J-M. 1998. The origin of west European subspecies of honey bees (Apis mellifera): new insights from microsatellite and mitochondrial data. Evolution 52:1119-34

30. Franck P, Garnery L, Solignac M, Cornuet J-M. 2000. Molecular confirmation of a fourth lineage in honey bees from the Near East. Apidologie 31:167-80

31. Garnery L, Mosshine EH, Cornuet J-M. 1995. Mitochondrial DNA variation in Moroccan and Spanish honey bee populations. Mol. Ecol. 4:465-71

32. Garnery L, Solignac M, Celebrano G, Cornuet J-M. 1993. A simple test using restricted PCR-amplified mitochondrial DNA to study the population structure of Apis mellifera L. Experientia 49:1016-21

33. Guzmán-Novoa E, Hunt GJ, Uribe JL, Smith C, Arechavaleta-Velasco ME. 2002. Confirmation of QTL effects and evidence of genetic dominance of honey bee defensive behavior: results of colony 
and individual behavioral assays. Behav. Genet. 32:95-102

34. Guzmán-Novoa E, Page RE Jr. 1993. Backcrossing Africanized honey bee queens to European drones reduces colony defensive behavior. Ann. Entomol. Soc. Am. 86:352-55

35. Guzmán-Novoa E, Page RE Jr. 1994. Genetic dominance and worker interactions affect honey bee colony defense. Behav. Ecol. 5:91-97

36. Guzmán-Novoa E, Page RE Jr. 1994. The impact of Africanized bees on Mexican beekeeping. Am. Bee J. 134:101-6

37. Guzmán-Novoa E, Page RE Jr. 1999. Selective breeding of honey bees (Hymenoptera: Apidae) in Africanized areas. J. Econ. Entomol. 92:521-25

38. Guzmán-Novoa E, Page RE Jr. 2000. Pollen collection and foraging force by European and European X Africanized hybrid honey bees (Hymenoptera: Apidae) in mixed genotype colonies are similar. Ann. Entomol. Soc. Am. 93:141-44

39. Guzmán-Novoa E, Page RE Jr. 2002. Successful selective breeding of honey bees in Africanized areas of Mexico. See Ref. 25, pp. $43-49$

40. Guzmán-Novoa E, Sanches A, Page RE Jr, Garcia T. 1996. Susceptibility of European and Africanized honey bees (Apis mellifera L.) and their hybrids to Varroa jacobsoni Oud. Apidologie 27:93-103

41. Guzmán-Novoa E, Vandame R, Arechavaleta ME. 2002. Tolerance to Varroa jacobsoni Oud. of honey bee (Apis mellifera L.) colonies in Mexico. See Ref. 25, pp. 80-85

42. Hall HG. 1990. Parental analysis of introgressive hybridization between African and European honey bees using nuclear RFLPs. Genetics 125:611-21

43. Hall HG. 1999. Genetic and physiological studies of African and European honey bee hybridizations: past, present and into the 21 st century. See Ref. 51, pp. 52-59

44. Hall HG, McMichael MA. 2001. Frequencies of restriction fragment-length polymorphisms indicate that Neotropical honey bee populations have African and West European origins. Ann. Entomol. Soc. Am. 94:670-76

45. Hall HG, Muralidharan K. 1989. Evidence from mitochondrial DNA that African honey bees spread as continuous maternal lineages. Nature 339:211-13

46. Hall HG, Smith DR. 1991. Distinguishing African and European honey bee matrilines using amplified mitochondrial DNA. Proc. Natl. Acad. Sci. USA 88:454852

47. Harrison JF, Hall HG. 1993. AfricanEuropean honey bee hybrids have low nonintermediate metabolic capacities. Nature 363:258-60

48. Hepburn HR, Radloff SE. 1998. Honey Bees of Africa. Berlin: Springer-Verlag

49. Holway DA, Suarez AV. 1999. Animal behavior: an essential component of invasion biology. Trends Ecol. Evol. 14:32830

50. Holway DA, Suarez AV, Case TJ. 1998. Loss of intraspecific aggression in the success of a widespread invasive social insect. Science 282:949-52

51. Hoopingarner R, Connor L, eds. 1999. Apiculture for the 21st Century. Cheshire, CT: Wicwas

52. Hunt GJ, Guzmán-Novoa E. 2002. Behavioral genetics of defensive behavior in Africanized honey bees. See Ref. 25, pp. 95-103

53. Hunter LA, Jackman JA, Sugden EA. 1993. Detection records of Africanized honey bees in Texas during 1990, 1991 and 1992. Southwest. Entomol. 18:79-89

54. Kerr WE, de Leon del Rio S, Barrionuevo MD. 1982. The southern limits of the distribution of the Africanized honey bee in South America. Am. Bee. J. 122:196-98

55. Kraus B, Page RE Jr. 1995. Effect of Varroa jacobsoni (Mesostigmata: Varroidae) on feral Apis mellifera (Hymenoptera: Apidae) in California. Environ. Entomol. 24:1473-80

56. Lobo JA. 1995. Morphometric, isozymic 
and mitochondrial variability of Africanized honey bees in Costa Rica. Heredity 75:133-41

57. Lobo JA, del Lama MA, Mestriner MA. 1989. Population differentiation and racial admixture in the Africanized honey bee (Apis mellifera L.). Evolution 43:794802

58. Lobo JA, Krieger H. 1992. Maximum likelihood estimates of gene frequencies and racial admixture in Apis mellifera L. (Africanized honey bees). Heredity 68:441-48

59. Loper GM. 2002. Nesting sites, characterization and longevity of feral honey bee colonies in the Sonoran desert of Arizona: 1991-2000. See Ref. 25, pp. 86-96

60. Loper GM, Fewell J, Smith DR, Sheppard WS, Schiff N. 1999. Changes in the genetics of a population of feral honey bees (Apis mellifera L.) in S. Arizona after the impact of tracheal mites (Acarapis woodi), Varroa mites (Varroa jacobsoni) and Africanization. See Ref. 51, pp. 4751

61. McMichael M, Hall HG. 1996. DNA RFLPs at a highly polymorphic locus distinguish European and African subspecies of the honey bee, Apis mellifera L., and suggest geographical origins of New World honey bees. Mol. Ecol. 5:40316

62. McNally LC, Schneider SS. 1992. Seasonal cycles of growth, development and movement of the African honey bee, Apis mellifera scutellata, in Africa. Insectes Soc. 39:167-79

63. McNally LC, Schneider SS. 1996. Spatial distribution and nesting biology of colonies of the African honey bee Apis mellifera scutellata (Hymenoptera: Apidae) in Botswana, Africa. Environ. Entomol. 25:643-52

64. Michener CD. 1975. The Brazilian bee problem. Annu. Rev. Entomol. 20:399416

65. Moritz RFA, Cornuet J-M, Kryger P, Garnery L, Hepburn HR. 1994. Mitochon- drial DNA variability in south African honey bees (Apis mellifera L.). Apidologie 25:169-78

66. Morse RA, Calderone NW. 2000. The value of honey bees as pollinators of U.S. crops in 2000. Bee Culture 127:1-15

67. Nielsen DI, Ebert PR, Hunt GJ, GuzmánNovoa E, Kinnee SA, Page RE Jr. 1999. Identification of Africanized honey bees (Hymenoptera: Apidae) incorporating morphometrics and an improved polymerase chain reaction mitotyping procedure. Ann. Entomol. Soc. Am. 92: 167-74

68. Nielsen DI, Ebert PR, Page RE Jr, Hunt GJ, Guzmán-Novoa E. 2000. Improved polymerase chain reaction-based mitochondrial genotype assay for identification of the Africanized honey bee (Hymenoptera: Apidae). Ann. Entomol. Soc. Am. 93:1-6

69. Oldroyd BP, Clifton MJ, Parker K, Wongsiri S, Rinderer TE, Corzier RH. 1998. Evolution of mating behaviour in the genus Apis and an estimate of mating frequency in Apis cerana (Hymenoptera: Apidae).Ann. Entomol. Soc. Am. 91:7009

70. Otis GW. 1991. Population biology of the Africanized honey bee. See Ref. 121, pp. 213-34

71. Otis GW, Talyor OR, Winston ML. 2002. Colony size affects reproductive attributes of African honey bees (Apis mellifera L.). See Ref. 25, pp. 25-32

72. Page RE Jr, Fondrk MK, Hunt GJ, Guzmán-Novoa E, Humphries MA, et al. 2000. Genetic dissection of honey bee (Apis mellifera) foraging behavior. $J$. Hered. 91:474-79

73. Palmer AR. 1994. Fluctuating asymmetry analyses: a primer. In Developmental Instability: Its Origins and Evolutionary Implications, ed. TA Markow, pp. 335-64. Dordrecht, Neth.: Kluwer

74. Palmer MR, Smith DR, Kaftanoğlu O. 2000. Turkish honey bees: genetic variation and evidence for a fourth lineage of 
Apis mellifera mtDNA. J. Hered. 91:4246

75. Pimentel D, Lach L, Zuniga R, Morrison D. 2000. Environmental and economic costs of non-indigenous species in the United States. Bioscience 50:53-65

76. Quezada-Euán JJG. 2000. Hybridization between European and Africanized honey bees in tropical Yucatan, Mexico. II. Morphometric, allozymic and mitochondrial DNA variability in feral colonies. Apidologie 31:1-10

77. Quezada-Euán JJG, Echazarreta CM, Paxton RJ. 1996. The distribution and range of expansion of Africanized honey bees (Apis mellifera) in the state of Yucatan, Mexico. J. Apic. Res. 35:8595

78. Quezada-Euán JJG, Hinsull SM. 1995. Evidence of continued European morphometrics and mtDNA in feral colonies of honey bees (Apis mellifera) from the Yucatan Peninsula. J. Apic. Res. 34:16166

79. Quezada-Euán JJG, May-Itza WDJ. 2001. Partial seasonal isolation of African and European-derived Apis mellifera (Hymenoptera: Apidae) drones at congregation areas from subtropical Mexico. Ann. Entomol. Soc. Am. 94:540-44

80. Quezada-Euán JJG, Medina LM. 1998. Hybridization between European and Africanized honey bees (Apis mellifera L.) in tropical Yucatan, Mexico. I. Morphometric changes in feral and managed colonies. Apidologie 29:555-68

81. Quezada-Euán JJG, Paxton RJ. 1999. Rapid intergenerational changes in morphology and behaviour in colonies of Africanized and European honey bees (Apis mellifera) from tropical Yucatan, Mexico. J. Apic. Res. 38:93-104

81a. Quezada-Euán JJG, Pérez-Castro E, May-Itzá WDJ. 2003. Hybridization between European and African-derived honeybee populations (Apis mellifera) at different altitudes in Perú. Apidologie $34: 217-25$
82. Ratnieks F, Visscher PK. 1996. Agricultural impact of Africanized honey bees in Sinaloa, Mexico. Calif. Agric. 50:2428

83. Rinderer TE. 1986. Africanized bees: the Africanization process and potential range in the United States. Bull. Entomol. Soc. Am. 32:222-27

84. Rinderer TE, Buco SM, Rubink WL, Daly HV, Stelzer JA, et al. 1993. Morphometric identification of Africanized and European honey bees using large reference populations. Apidologie 24:569-85

85. Rinderer TE, Collins AM, Hellmich RL, Danka RG. 1987. Differential drone production by Africanized and European honey bee colonies. Apidologie 18:6168

86. Rinderer TE, Hellmich RL, Danka RG, Collins AM. 1985. Male reproductive parasitism: a factor in the Africanization of European honey bee populations. Science 228:1119-21

87. Rinderer TE, Oldroyd BP, Sheppard WS. 1993. Africanized bees in the U.S. Sci. Am. 269:84-90

88. Rinderer TE, Stelzer JA, Oldroyd BP, Buco SM, Rubink WL. 1991. Hybridization between European and Africanized honey bees in the Neotropical Yucatan Peninsula. Science 253:309-11

89. Rosenkranz P, Garrido G, Stürmer M. 2002. Initiation and control of Varroa reproduction in worker brood of Apis mellifera. See Ref. 25, pp. 132-38

90. Rosenkranz P, Kirsch R, Stürmer M. 2002. Population dynamics of honey bees, honey bee brood and Varroa mites in untreated colonies in Uruguay. See Ref. 25, pp. 188-90

91. Rubink WL, Luevano-Martinez P, Sugden EA, Wilson WT, Collins AM. 1996. Subtropical Apis mellifera (Hymenoptera: Apidae) swarming dynamics and Africanization rates in northeastern Mexico and southern Texas. Ann. Entomol. Soc. Am. 89:243-51

92. Ruttner F. 1988. Biogeography and 
Taxonomy of Honey Bees. Berlin: Springer-Verlag

93. Schiff NM, Sheppard WS. 1993. Mitochondrial DNA evidence for the 19th century introduction of African honey bees into the United States. Experientia 49:350-52

94. Schiff NM, Sheppard WS. 1995. Genetic analysis of commercial honey bees (Hymenoptera: Apidae) from the southern United States. J. Econ. Entomol. 88:121620

95. Schiff NM, Sheppard WS, Loper GR, Shimanuki H. 1994. Genetic diversity of feral honey bee (Hymenoptera: Apidae) populations in the Southern United States. Ann. Entomol. Soc. Am. 87:842-48

96. Schneider SS. 1995. Swarm movement patterns inferred from waggle dance activity of the Neotropical African honey bee in Costa Rica. Apidologie 26:395406

97. Schneider SS, DeGrandi-Hoffman G. 2002. The influence of worker behavior and paternity on the development and emergence of honey bee queens. Insectes Soc. 49:306-14

98. Schneider SS, DeGrandi-Hoffman G. 2003. The influence of paternity on virgin queen success in hybrid colonies of European and African honey bees, Apis mellifera. Anim. Behav. 65:883-92

99. Schneider SS, Hall HG. 1997. Diet selection and foraging distances of African and European-African hybrid honey bee colonies in Costa Rica. Insectes Soc. 44:171-87

99a. Schneider SS, Leamy LJ, Lewis LA, DeGrandi-Hoffman G. 2003. The influence of hybridization between African and European honey bees, Apis mellifera, on asymmetries in wing size and shape. Evolution. 57: In press

100. Schneider SS, McNally LC. 1992. Factors influencing seasonal absconding in colonies of the African honey bee, Apis mellifera scutellata. Insectes Soc. 39:403-23
101. Schneider SS, McNally LC. 1993. Spatial foraging patterns and colony energy status in the African honey bee, Apis mellifera scutellata. J. Insect Behav. 6:195210

102. Schneider SS, McNally LC. 1994. Waggle dance behavior associated with seasonal absconding in colonies of the African honey bee, Apis mellifera scutellata. Insectes Soc. 41:115-27

103. Schneider SS, Painter-Kurt S, DeGrandiHoffman G. 2001. The role of the vibration signal during queen competition in colonies of the honey bee, Apis mellifera. Anim. Behav. 61:1173-80

104. Segura JAL. 2000. Highly polymorphic DNA markers in an Africanized honey bee population in Costa Rica. Genet. Mol. Biol. 23:317-22

105. Sheppard WS. 1989. A history of the introduction of honey bee races into the United States. Am. Bee J. 129:617-19, 664-67

106. Sheppard WS. 2002. Diversity of Africanized honey bees in the United States and the utility of mitochondrial DNA origins. See Ref. 25, pp. 60-64

107. Sheppard WS, Rinderer TE, Garnery L. 1999. Analysis of Africanized honey bee mitochondrial DNA reveals further diversity of origin. Genet. Mol. Biol. 22:7375

108. Sheppard WS, Rinderer TE, Mazzoli JA, Stelzer JA, Shimanuki H. 1991. Gene flow between African- and European-derived honey bee populations in Argentina. $\mathrm{Na}$ ture 349:782-84

109. Sheppard WS, Rinderer TE, Meixner MD, Yoo HR, Stelzer JA, et al. 1996. Hin F1 variation in mitochondrial DNA of Old World honey bee races. J. Hered. 87:3540

110. Sheppard WS, Smith DR. 2000. Identification of African-derived bees in the Americas: a survey of methods. Ann. Entomol. Soc. Am. 93:159-76

111. Sheppard WS, Soares AEE, DeJong D, Shimanuki H. 1991. Hybrid status of 
honey bee populations near the historic origin of Africanization in Brazil. Apidologie 22:643-52

112. Simberloff D. 2000. Nonindigenous species: a global threat to biodiversity and stability. In Nature and Human Society: A Quest for a Sustainable World, ed. P Raven, T William, pp. 325-34. Washington, DC: Natl. Acad. Press

113. Smith DR. 1991. African bees in the Americas: insights from biogeography and genetics. Trends Ecol. Evol. 6:1721

114. Smith DR. 1991. Mitochondrial DNA and honey bee biogeography. In Diversity in the Genus Apis, ed. DR Smith, pp. 13176. Boulder, CO: Westview

115. Smith DR, Crespi BJ, Bookstein FL. 1997. Fluctuating asymmetry in the honey bee, Apis mellifera: effects of ploidy and hybridization. J. Evol. Biol. 10:55174

116. Smith DR, Palopoli MF, Taylor BR, Garnery L, Cornuet JM, et al. 1991. Geographical overlap of two mitochondrial genomes in Spanish honey bees (Apis mellifera iberica). J. Hered. 82:96-100

117. Smith DR, Taylor OR, Brown WW. 1989. Neotropical Africanized honey bees have African mitochondrial DNA. Nature 339:213-15

118. Sousa RM, Freitas BM, de Araújo ZB, Soares AEE. 2002. Seasonal changes in Africanized honey bee (Apis mellifera L.) population of the Caatinga vegetation in NE Brazil. See Ref. 25, pp. 16-24

119. Spivak M. 1992. The relative success of Africanized and European honey-bees over a range of life-zones in Costa Rica. J. Appl. Ecol. 29:150-62

120. Spivak M, Fletcher DJC, Breed MD. 1991. Introduction. See Ref. 121, pp. 112

121. Spivak M, Fletcher DJC, Breed MD, eds. 1991. The "African" Honey Bee. Boulder, CO: Westview

122. Suazo A, Hall HG. 2002. Nuclear DNA PCR-RFLPs that distinguish African and
European honey bee groups of subspecies.

I. Comparison of long PCR and standard PCR to screen for polymorphisms. Biochem. Genet. 40:225-39

123. Suazo A, Hall HG. 2002. Nuclear DNA PCR-RFLPs that distinguish African and European honey bee groups of subspecies. II. Conversion of long PCR markers to standard PCR. Biochem. Genet. 40:24161

124. Suazo A, Lee M-L, Hall HG. 2002. A locus with restriction fragment-length polymorphisms characteristic of African and European honey bee (Hymenoptera: Apidae) groups of subspecies. Ann. Entomol. Soc. Am. 95:115-24

125. Suazo A, McTiernan R, Hall HG. 1998. Differences between African and European honey bees (Apis mellifera L.) in random amplified polymorphic DNA (RAPD). J. Hered. 89:32-36

126. Taylor OR. 1999. Displacement of European honey bee subspecies by an invading African subspecies in the Americas. See Ref. 51, pp. 38-46

127. Taylor OR. 2003. Neotropical African (killer) bees. In Encyclopedia of Insects, ed. V Resh, R Cardé, pp. 776-78. New York: Academic

128. Vandame R, Colin M. 2002. Removal behavior of artificially auto-infested brood by honey bees of different Africanization levels. See Ref. 25, pp. 290-95

129. Vergara C, Dietz A, Perez de Leon A. 1993. Female parasitism of European honey bees by Africanized honey bee swarms in Mexico. J. Apic. Res. 32:3440

130. Villa JD, Koeniger N, Rinderer TE. 1991. Overwintering of Africanized, European and hybrid honey bees in Germany. Environ. Entomol. 20:39-43

131. Villa JD, Rinderer TE, Collins AM. 1993. 'Overwintering' of Africanized, European, and hybrid honey bees in the Andes of Venezuela. Environ. Entomol. 22:18389

132. Villa JD, Rinderer TE, Stelzer JA. 2002. 
Answers to the puzzling distribution of Africanized bees in the United States. Am. Bee J. 142:480-483

133. Visscher PK, Vetter RS, Baptista FC. 1997. Africanized bees, 1990-1995: Initial rapid expansion has slowed in the U.S. Calif. Agric. 51:22-25

134. Winston ML. 1992. Killer Bees: The Africanized Honey Bee in the Amer- icas. Cambridge, MA: Harvard Univ. Press

135. Winston ML. 1992. The biology and management of Africanized honey bees. Annu. Rev. Entomol. 37:173-93

136. Zillikens A, Simões ZLP, Engels W. 1998. Higher fertility of queenless workers in the Africanized honey bee. Insectes. Soc. 45:473-76 
急 Annual Review of Entomology

Volume 49, 2004

\section{CONTENTS}

FRONTISPIECE, Benjamin Dann Walsh

xiv

BENJAMIN DANN WALSh: PiONEER ENTOMOLOGIST AND PROPONENT OF DARWINIAN THEORY, Carol A. Sheppard

FUNCTIONAL ECOLOGY OF IMMATURE PARASITOIDS, Jacques Brodeur and Guy Boivin

InSECT WALKING AND RoBOTICS, Fred Delcomyn

THE GUT BACTERIA OF INSECTS: NONPATHOGENIC INTERACTIONS, R.J. Dillon and V.M. Dillon

REGULATION OF INTERMEDIARY METABOLISM AND WATER BALANCE OF INSECTS BY NEUROPEPTIDES, Gerd Gäde

LONG-TERM, LARGE-SCALE BIOMONITORING OF THE UNKNOWN: ASSESSING THE EFFECTS OF INSECTICIDES TO CONTROL RIVER BLINDNESS (ONCHOCERCIASIS) IN WEST AFRICA, Vincent H. Resh, Christian Lévêque, and Bernhard Statzner

VENEZUELAN EQuine ENCEPHALITIS, Scott C. Weaver, Cristina Ferro, Roberto Barrera, Jorge Boshell, and Juan-Carlos Navarro

GALLING APHIDS: SPECIALIZATION, BIOLOGICAL COMPLEXITY, AND VARIATION, David Wool

POPULATION GENETICS OF AUTOCIDAL CONTROL AND STRAIN

REPLACEMENT, Fred Gould and Paul Schliekelman

Biological CONTROL of CEREAL APHIDS IN NORTH AMERICA AND Mediating EFFeCts of Host Plant AND Habitat MANIPULATIONS, M.J. Brewer and N.C. Elliott

The Biology of XYLEM Fluid-FeEding InSECT VeCTORS OF XYLELLA FASTIDIOSA AND THEIR RELATION TO DISEASE EPIDEMIOLOGY, Richard A. Redak, Alexander H. Purcell, João R.S. Lopes, Matthew J. Blua, Russell F. Mizell III, and Peter C. Andersen

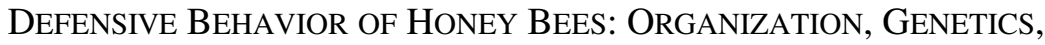
AND COMPARISONS WITH OTHER BEES, Michael D. Breed,

Ernesto Guzmán-Novoa, and Greg J. Hunt 
WASP PARASITOID DISRUPTION OF HOST DEVELOPMENT:

IMPLICATIONS FOR NEW BIOLOGICALLY BASED STRATEGIES FOR

INSECT CONTROL, Nancy E. Beckage and Dale B. Gelman

ERAdiCATION OF THE MELON FLy, BACTROCERA CUCURBITAE, IN

JAPAN: IMPORTANCE OF BEHAVIOR, ECOLOGY, GENETICS, AND

EVOLUTION, Juro Koyama, Hiroyuki Kakinohana, and Takahisa Miyatake

THE AFriCAN HONEY BEE: FACTORS CONTRIBUTING TO A

SUCCESSFUL BIOLOGICAL INVASION, Stanley Scott Schneider,

Gloria DeGrandi-Hoffman, and Deborah Roan Smith

PHYlOGENY AND BiOlogy OF NeOTROPICAL ORCHID BeES

(Euglossini), Sydney A. Cameron

Plant-InSECT INTERACTIONS IN FRAGMENTED LANDSCAPES,

Teja Tscharntke and Roland Brandl

405

POLYDNAVIRUS GENES AND GENOMES: EMERGING GENE FAMILIES AND NEW INSIGHTS INTO POLYDNAVIRUS REPLICATION, Jeremy A. Kroemer and Bruce A. Webb

HuMAN LICE AND THEIR CONTROL, Ian F. Burgess

INDEXES

Subject Index

Cumulative Index of Contributing Authors, Volumes 40-49

505

Cumulative Index of Chapter Titles, Volumes 40-49

\section{ERRATA}

An online log of corrections to Annual Review of Entomology chapters may be found at http://ento.annualreviews.org/errata.shtml 